\title{
Formação docente e o Ensino Religioso: resultado preliminar de levantamento sobre teses e dissertações no Brasil
}

\author{
Teacher training and Religious Education: survey's \\ preliminary results on theses and dissertations in Brazil
}

\section{Maria Eliane Azevedo da Silva ${ }^{[a]}$,Afonso Maria Ligorio Soares ${ }^{[b]}$}

[a] Mestranda em Ciências da Religião pela Pontifícia Universidade Católica de São Paulo (PUC-SP), Pós-Graduada em Administração Escolar, Graduada em Psicologia e Pedagogia, São Paulo, SP - Brasil, e-mail: azevedo_el@hotmail.com

${ }^{[b]}$ Livre-docente em Teologia e Doutor em Ciências da Religião, pesquisador do Programa de Estudos Pós-Graduados em Ciências da Religião na Pontifícia Universidade Católica de São Paulo (PUC-SP), Paulo, SP - Brasil, e-mail: sofona@uol.com.br

\section{Resumo}

Este artigo pretende apresentar uma visão geral das dissertações e teses defendidas em universidades brasileiras na área da Educação cuja temática principal seja a formação docente e o Ensino Religioso. Constatou-se a existência de cerca de 50 teses e dissertações a respeito do Ensino Religioso, sendo a Pontifícia Universidade Católica do Paraná (PUCPR) a que detém o maior número de pesquisas sobre o 
assunto. A seleção do material obedeceu a três eixos, a fim de enuclear os assuntos pesquisados: formação do professor; finalidades e currículo; e material didático e subsídios para a formação docente. As temáticas levantadas nesta proposta inicial de discussão apresentam-se interligadas e concentram-se nas seguintes questões: concepção do sagrado e do Ensino Religioso; ritos, símbolos, afetividade e mediação; cultura e cidadania; perfil do professor de Ensino Religioso; práticas curriculares e prática docente; subsídios para a formação docente; e o fazer pedagógico.

Palavras-chave: Formação docente. Ensino Religioso. Fazer pedagógico.

\section{Abstract}

This article intends to expose a general vision of the dissertations and theses in the area of the Education in order to focus on the educational formation and the Religious Education. We have found out the existence of about 50 theses and dissertations that researches Religious Education, and the Pontificia Universidade Católica do Paraná (PUCPR) is the university with the majority of papers concerning the theme. Material's selection has obeyed three main points in order to organize the works: educational formation; purposes and curricula; and school-books and subsidies to the teaching formation. The themes in this introductory approach are interconnected and concentrate in the following subjects: the concept of the holy and of the Religious Education; rites, symbols, affectivity and mediation; culture and citizenship; the profile of the of the Religious Education teacher; curricular and educational practices; subsidies for teacher's formation; and the pedagogical making.

Keywords: Teacher's formation. Religious Education. Pedagogical making.

\section{Introdução}

O Grupo de Pesquisa Religião \& Educação, ligado ao Programa de Estudos Pós-Graduados em Ciências da Religião da Pontifícia Universidade Católica de São Paulo (PUC-SP) vem fazendo um levantamento exaustivo sobre a ocorrência do tema Ensino Religioso (ER) nos programas de pós- 
graduação das universidades brasileiras e demais instituições de ensino superior (IES). Este artigo vai se deter nas pesquisas desenvolvidas na área da Educação nessas universidades. Nesse âmbito, constatou-se a existência de cerca de 50 teses e dissertações relativas ao Ensino Religioso, sendo a Pontifícia Universidade Católica do Paraná (PUCPR) a que detém o maior número de dissertações sobre o assunto.

Em um primeiro momento, procurou-se selecionar o material, fazendo a leitura dos resumos, e fomos percebendo a amplitude dos assuntos abordados nas pesquisas. Assim, pensamos em agrupá-los em três eixos:

a) formação do professor, tema que prevalece na maioria das teses e dissertações selecionadas;

b) finalidades e currículo, que se apresentam com uma variedade de temáticas em estudo;

c) material didático e subsídios para a formação docente, objeto de estudo enfrentado em poucos trabalhos.

Considerando-se a ênfase maior dos estudos realizados com relação à formação dos professores de Ensino Religioso, foi estabelecida como foco do presente artigo a formação docente.

Portanto, este artigo aborda o eixo da formação do professor de Ensino Religioso, apresentando algumas das pesquisas realizadas na área de Educação. As temáticas levantadas nesta proposta inicial de discussão sobre o referido assunto apresentam-se interligadas e concentram-se em:

a) concepção do sagrado e do ER;

b) ritos, símbolos, afetividade e mediação;

c) cultura e cidadania;

d) perfil do professor de ER;

f) práticas curriculares e prática docente;

g) subsídios para a formação docente;

f) o fazer pedagógico.

A formação docente, na atualidade, é um tema bastante visado e requer práticas que possibilitem efetivas mudanças no campo da Educação. Portanto, a temática "formação docente e Ensino Religioso" é de importante relevância social, considerando a pessoa do professor, inserido em um 
contexto sociocultural, e um fazer pedagógico que contemple os quatro pilares da educação indicados por Jacques Delors (1996): o aprender a conhecer, aprender a fazer, aprender a conviver e aprender a ser.

A partir dessas premissas iniciais, pode-se pensar na relevância que tiveram, no momento histórico em que foram concebidos, os Parâmetros Curriculares Nacionais do Ensino Religioso (PCNER). Na sua apresentação do conhecimento religioso, tinham como base os questionamentos que o ser humano se faz sobre a própria existência: quem sou? De onde vim? Para onde vou?

Portanto, o ER remete ao fundamento da vida humana e integra o ser humano no estabelecimento de suas relações socioculturais, na busca do sentido da vida e na dimensão de transcendência.

Algumas das dissertações pesquisadas e selecionadas para discussão neste artigo apresentam de maneira significativa e desafiadora os processos de formação docente no Ensino Religioso, uma temática ainda com poucos estudos, mas com iniciativas estaduais que vêm sendo aprimoradas segundo a Lei de Diretrizes e Bases da Educação Nacional (LDBEN), os Parâmetros Curriculares Nacionais do Ensino Religioso (PCNER) e o Fórum Nacional Permanente do Ensino Religioso (Fonaper).

\section{Concepção do sagrado e do Ensino Religioso}

Bárbara Raquel do Prado Gimenez Corrêa (2006), na sua dissertação $A$ concep̧ção dos professores sobre o sagrado: implicações para a formação docente (PUCPR), comenta que os temas sociais, no mundo atual, são elementos de discussão, estudo, pesquisas, e que estas temáticas são objeto de investigação na escola, diante das necessidades do delineamento dos conteúdos, metodologias, avaliação, e formação docente, em vista da formação integral do indivíduo. A sua pesquisa qualitativa, com um grupo de professores da rede pública do Estado do Paraná, teve como objetivo investigar a concepção dos professores de Ensino Religioso sobre o objeto da disciplina em que atuam profissionalmente. Foram considerados nesta pesquisa as limitações do processo de formação inicial, a articulação com os saberes específicos e os conteúdos de ensino.

Segundo a autora, a temática do "sagrado" na atualidade é proveniente das diferentes movimentações socioculturais, apresentando-se 
de maneira complexa e dificultando definições deste objeto de estudo. No âmbito do ER e no espaço escolar, essa diversidade deve ser considerada na prática docente. De maneira pertinente, apresenta-se a pergunta: "como os professores que não possuem a formação inicial adequada estabelecem relações com objeto de estudo do Ensino Religioso, ou seja, que concepções os professores desta disciplina possuem sobre o sagrado?" (CORRÊA, p. 4).

A resposta a essa problemática é discutida a partir das seguintes explanações: os princípios legislativos, históricos e teóricos da disciplina de Ensino Religioso; análise dos dados coletados à luz de teorias sobre o objeto em estudo - o sagrado; inter-relações dos dados da pesquisa e o processo de formação docente; relação entre elementos teóricos na formação docente, limitações e avanços.

Alguns dos importantes aspectos levantados nesse estudo:

a) formação inicial dos docentes de ER: o maior número é formado em História, seguido de Pedagogia e Filosofia; outros atuam na disciplina sem a formação de indicação legal e são formados em Geografia, Letras, Educação Física, Psicologia, Ciências, Matemática, Química e Física; e 3\% não indicaram na pesquisa sua formação inicial;

b) cinco conceitos sobre a concepção do sagrado foram elencados, diante das respostas dos entrevistados e em consonância com os referenciais teóricos estudados: sagrado e religião, sagrado e cultura, sagrado e transcendência, sagrado e valores, sagrado e sentimento;

c) a definição da concepção de sagrado implica objetividade e subjetividade, conhecimento científico do objeto da disciplina de Ensino Religioso e a prática - cotidiano religioso no qual o professor está inserido;

d) formação continuada, como exigência para aquisição de um diploma, como plano de carreira e não como um valor formador - constatase a fragilidade do processo de formação continuada;

e) dificuldade na prática em sala de aula, por causa da falta de licenciatura;

f) limitação e escassez de referenciais teóricos sobre o sagrado, sobre a vinculação com o Ensino Religioso e a prática pedagógica;

g) questionamento: diante da concepção de sagrado ligado à prática de fé, como o docente irá realizar a transposição didática em sala de aula? 
h) o questionamento citado no item anterior é apresentado como proposta de continuidade de estudos na área;

i) a prática docente no ER requer tratar o conhecimento religioso construído culturalmente, superando o espontaneísmo epragmatismo; j) o processo formativo inicial e continuado deve colocar o docente em postura de indagação, realizando pesquisas, relações e confrontos teóricos, para produção de novos saberes e significação dos já existentes.

A autora considera como o maior desafio dessa pesquisa os pressupostos necessários para a formalização da formação dos professores, o que abre possibilidades para novos estudos.

$\mathrm{Na}$ dissertação Em riscos e rabiscos: concepções de ensino religioso dos docentes do ensino fundamental do Estado do Paraná - possibilidade para uma formação docente (PUCPR), a autora Edile Maria Fracaro Rodrigues (2008) apresenta uma investigação da concepção dos professores sobre o ER. O perfil e a formação docente são levantados na pesquisa, considerando-se a subjetividade presente nas frases e desenhos elaborados pelos sujeitos da pesquisa e apontando caminhos para uma específica formação para o Ensino Religioso. A análise dos dados coletados sugere uma superação das aulas tradicionais de Religião e constata-se que os professores estão buscando inserir em suas aulas conteúdos referentes à diversidade religiosa.

A concepção de ER dos professores apresentada nessa dissertação enquadra dois modelos: um interconfessional ou inter-relacional (transmissão e desenvolvimento de valores, moral e ética, respostas às questões existenciais); e um modelo fenomenológico (estudo das tradições religiosas, manifestações do sagrado). Apenas um documento apontou o modelo confessionalidade, portanto, este não foi contemplado na análise da pesquisa.

A contribuição dos livros didáticos é importante na formação de professores, e esses devem ser elaborados a partir de uma abordagem fenomenológica, auxiliando os alunos no enfrentamento dos seus conflitos existenciais, ajudando-os a desenvolver a religiosidade própria de cada um e a ter uma ação dialógica diante das diferentes expressões religiosas.

Ao fim, a autora comenta que o Ensino Religioso, como área de conhecimento, deve possibilitar uma maior abertura e compromisso dos educandos e educadores consigo mesmos, com o outro, com o mundo e com o transcendente. 


\section{Ritos, símbolos, afetividade e mediação}

Erlei Antonio Vieira (2006) pesquisa em sua dissertação Os ritos (PUCPR) e os vê como um dos eixos organizadores do currículo do Ensino Religioso e da formação do professor, notando sua influência na formação docente. Enfatiza que a vida humana real se encarna em ritos, que o ser humano se exprime por meio de gestos, símbolos e palavras portadoras de significado. Para ele, as pessoas relacionam-se umas com as outras em torno de uma significação e os ritos são expressões de valores e símbolos, consolidando a comunidade, servindo como veículos de transmissão de outras formas de viver e entender a vida.

A proposta desse estudo engloba a teoria dos ritos como elemento para a formação docente no ER e a sua releitura de mundo. Algumas constatações da pesquisa: os docentes carecem de saberes básicos para a disciplina; possuem uma ideia vaga sobre o rito; apresentam deficiência no conhecimento das tradições religiosas e dos PCNs e PCNERs. A partir desta realidade, percebeu-se a necessidade de uma licenciatura em Ensino Religioso e a importância de grupos de estudo para a formação docente. $O$ autor sugere que futuras pesquisas possam ser desenvolvidas incluindo: o rito - aspectos antropológicos, sociológicos, psicológicos e outros; projetos de formação de professores de ER dentro da legislação atual para a disciplina; estudo detalhado sobre mitos e símbolos na vida pessoal e profissional dos professores ou alunos de Ensino Religioso, ou de outros grupos sociais pré-determinados.

Emerli Schlögl (2005) focaliza, na dissertação Não basta abrir as janelas: o simbólico na formação do professor, a conceituação e as características da estruturação da simbologia no Ensino Religioso. Em sua pesquisa evidenciouse que é preciso articular um diálogo entre aquilo que se conhece e aquilo que se deseja conhecer. Outro aspecto apresentado é que os significados e significantes pessoais podem auxiliar ou impedir o contato direto e a compreensão dos significantes e significados de outras culturas religiosas.

Percebeu-se que a compreensão simbólica do professor se dá de forma parcelada, não garantindo a liberdade de se relacionar com símbolos de culturas diferentes. É limitado o conhecimento do professor sobre os códigos simbólicos e ele não está acostumado a estabelecer relações com o universo multicultural do povo brasileiro. Os professores, em sua maioria, revelam encantamento e satisfação na reflexão sobre os símbolos, o que abre possibilidades para estudo e reflexão relativos a essa temática. 
Iracildo Pereira Castro (2008), em dissertação defendida na Universidade Federal do Pará, estudou a Afetividade e mediação do professor do Ensino Religioso Escolar. Ele apresenta na sua proposta de estudo a análise da importância do vínculo afetivo na mediação entre o professor de ER e o aluno de ensino fundamental. Em seu trabalho buscou respostas para a questão: "Qual a importância da mediação afetiva entre o professor de ensino religioso e os alunos do ensino fundamental para o processo ensinoaprendizagem?"' (CASTRO, 2008, p. 26).

No decorrer do estudo, procurou-se compreender como os professores constroem e reconstroem seus saberes e fazeres, considerando os aspectos afetivo-emocionais no cotidiano da sala de aula. Foi constatado que afetividade e cognição se entrecruzam, são independentes e fazem parte de um mesmo processo.

O trabalho de Castro sugere a existência de uma articulação entre o afetivo e o cognitivo nas atividades em sala de aula, e que a mediação afetiva possibilita a configuração significativa do conteúdo ensinado.

\section{Cultura e cidadania}

Liliana Claúdia Seehaber (2006), em dissertação apresentada na PUCPR, Cultura, lente pela qual se vê o mundo: o universo cultural do professor de ensino religioso, investiga a concepção de cultura na formação de professores de ER. Na pesquisa de campo, notou-se que a concepção de cultura do professor de Ensino Religioso é fragmentada, revelando uma confusão diante do conceito, mas não descartando que o tema cultura é fundamental na constituição de valores e na construção cidadã de uma sociedade justa e solidária.

A autora considera a diversidade religiosa e cultural, e vislumbra um curso de Licenciatura em Ensino Religioso, destacando os PCNER na sua proposição sobre formação docente que inclua a concepção cultural dos indivíduos. A partir desse estudo evidenciou-se que a cultura apresentase como uma teia de significados e significações para dar sustentação à convivência humana no mundo.

Já a dissertação de Léo Marcelo Plantes Machado (2006), Acidadania na formação de professores para ensino religioso (PUCPR), levanta a seguinte pergunta: como a questão da cidadania está contemplada na formação de professores para a área de Ensino Religioso? 
O estudo teve por objetivo compreender as concepções de cidadania que o professor de ER possui e reproduz ao exercer a sua profissão. Os dados da pesquisa de campo evidenciaram a apresentação da cidadania como pressuposto para o reconhecimento e respeito da dignidade humana.

O autor comenta que a formação docente supõe a mobilização de práticas pedagógicas solidárias, democráticas e reflexivas sobre a realidade social, considerando-se a diversidade religiosa no contexto brasileiro. Destaca também que o professor deve ter como princípio cidadão elevar a consciência e participação de seus educandos, com autonomia e respeito.

Nas considerações finais, comenta-se que a educação e o professor estão longe de concretizar uma prática que desafie os educandos ao exercício pleno da cidadania.

\section{Perfil do professor de Ensino Religioso}

Silvana Fortaleza dos Santos (2007) investigou em seu mestrado na PUCPR o Perfil do professor de Ensino Religioso da educaşão infantil e dos anos iniciais do ensino fundamental na Escola Confessional Católica. Ela abordou as características da escola confessional católica e o seu projeto educativo; o ER como área de conhecimento; a formação inicial e continuada.

A análise dos dados coletados na pesquisa de campo possibilitou o levantamento de informações para a identificação do perfil do professor. Os resultados evidenciaram, como era previsível, a necessidade de maior investimento nos cursos de formação continuada, em virtude da deficiência da formação inicial dos professores.

Eis sua apresentação das características dos professores: $97,16 \%$ são do sexo feminino; $78 \%$ possuem idade entre 20 a 40 anos de idade; $90,07 \%$ são praticantes da religião católica; $80,14 \%$ com graduação em Pedagogia; $41,84 \%$ possuem mais de cinco anos de tempo de serviço na mesma escola; $52 \%$ têm uma jornada de 20 horas semanais; $95,04 \%$ são professores generalistas; $62,41 \%$ declararam que nunca participaram de curso de capacitação em Ensino Religioso; 36,17\% têm o hábito de leitura de revistas especializadas em educação; 68,09\% têm acesso à internet e utilizam recursos tecnológicos para elaboração de planejamentos e provas. Um dado relevante, e incomum no Brasil, é que todos os professores são graduados. 
Essas informações merecem que sejam ressaltados alguns aspectos. Em primeiro lugar, o contexto atual apresenta o desafio da construção de um novo cidadão, por meio do fazer pedagógico do professor de ER. Além disso, registre-se o seguinte: a deficiência na formação inicial; a necessidade de investimento na preparação profissional; a formação continuada (que deve estar agregada ao projeto da escola); a importância de espaços de discussão na escola, sobre as dificuldades e avanços na prática do Ensino Religioso; e a responsabilidade social dessa disciplina para garantir a democracia e o multiculturalismo.

Douglas Jeferson Menslin (2009), na dissertação de Mestrado Perfil do professor de ensino religioso nos anos iniciais do ensino fundamental da rede educacional adventista no Sul do Brasil (PUCPR), teve como objetivo identificar o perfil do professor, procurando analisar a formação dos profissionais e ver como essa formação se relaciona com a filosofia proposta pela instituição onde atuam.

Entre as dificuldades analisadas na pesquisa, foram destacadas a necessidade de formação inicial e continuada para o professor de Ensino Religioso, a profissionalização docente e o desenvolvimento de habilidades e competências para este profissional. Os resultados apresentaram que o perfil do professor está sendo construído com a prática pedagógica, e não primariamente pela sua formação docente. Enfim, a pesquisa provocou uma reflexão sobre a prática e a filosofia, o real e o ideal para a formação dos professores e a oportunidade da continuidade de estudos sobre a formação profissional para a disciplina de ER.

A dissertação de Danise Cristiane Rios Araújo (2007), Características do professor de ensino religioso dos anos finais do ensino fundamental e médio nas escolas católicas de Curitiba (PUCPR), propôs-se a identificar as características dos professores a partir de sua formação, do material didático utilizado, do reconhecimento do ER como área de conhecimento e das dificuldades encontradas nesta disciplina.

Constatou-se que, de fato, não existe uma formação inicial específica e que a formação continuada fica comprometida, pois os educadores na maioria são de áreas diversificadas, não orientando, desta forma, a sua formação para a disciplina de Ensino Religioso.

Características dos professores de acordo com os dados obtidos: 54\% são do sexo feminino; 75\% têm idade entre 20 e 40 anos; 67\% são casados; $75 \%$ possuem especialização; $54 \%$ trabalham no estabelecimento entre 0 e 5 anos; 69\% trabalham com a disciplina Ensino Religioso; 62\% não 
possuem capacitação nessa disciplina; 46\% dos professores consideram-na como área de conhecimento; 49\% utilizam a metodologia de pesquisa-textos e debates nas aulas; $69 \%$ trabalham até 20 horas semanais e $59 \%$ utilizam a internet como recurso tecnológico para as aulas. Todos os professores são graduados, alguns nas áreas de Pedagogia e outros, na de Filosofia.

Considerando a realidade do profissional docente, a autora comenta a necessidade da criação de cursos de formação inicial, o aumento dos cursos de formação continuada, visando a fornecer ao professor a habilitação para a prática pedagógica e construção do conhecimento a partir do objeto da disciplina - o fenômeno religioso. Esse espaço formativo deve garantir a relação entre teoria e prática, visando ao Ensino Religioso como uma disciplina que favoreça o desenvolvimento crítico do aluno diante do fenômeno religioso e que ele aprenda a conviver com a diversidade religiosa no mundo atual.

\section{Práticas curriculares e prática docente}

Lurdes Caron (2007), em sua tese doutoral em Educação (PUC-SP), Politicas e práticas curriculares: formação de professores de ensino religioso, incumbiuse de identificar e analisar políticas e tendências atuais sobre a formação dos professores de ER no Estado de Santa Catarina, entre 1996 e 2006.

As questões norteadoras do trabalho foram: quais as políticas e práticas utilizadas para a formação de professores de Ensino Religioso em Santa Catarina? Quais os resultados alcançados?

A autora comenta que a legislação vigente requer professores com habilitação e competência, e buscou em seu estudo a contextualização do ER na história da educação brasileira; o conhecimento da posição de professores e acadêmicos egressos do curso de Ciências da Religião Habilitação Plena em Ensino Religioso; e buscou detectar políticas, tendências e resultados alcançados na formação de professores da disciplina. Caron, nas suas considerações finais, aponta que o Ensino Religioso, hoje, para que atenda a seus propósitos, necessita de políticas públicas na formação de professores. Outro aspecto apresentado é que a pesquisa poderá dar a sua contribuição social na organização dessas políticas, tendo em vista a formação continuada dos docentes.

Por sua parte, o mestre em Educação José Carlos Bertoni (2008) investigou em sua dissertação - Da legislação à prática docente: o ensino religioso 
nas escolas municipais de Santos (Universidade Presbiteriana Mackenzie) - a legislação, a concepção de Ensino Religioso, a capacitação e formação de professores, a descrição das expectativas e práticas dos docentes.

As perguntas levantadas foram: "Qual é a concepção do Ensino Religioso na nova legislação? Qual é a proposta pedagógica da formação continuada em ensino da religião? O professor ministra a disciplina sem direcionar (proselitismo)? O professor observa a diversidade cultural religiosa em sala de aula? Como o faz? O professor reflete sobre sua prática e tem clareza da mesma?” (BERTONI, 2008, p. 14).

$\mathrm{O}$ autor descobriu na pesquisa de campo que a maioria dos professores relatava que as aulas são trabalhadas de forma transversal com outras disciplinas, e que os professores percebem a necessidade da formação continuada e da criação de uma comunidade reflexiva para facilitação da troca de informações entre si.

Notou-se que, quanto ao processo formativo, a Secretaria de Educação do Município de Santos foi extremamente positiva na compreensão da necessidade de uma formação continuada em Ensino Religioso, buscando o comprometimento entre o discurso e a prática.

Vem da Universidade Federal do Piauí a dissertação de Napoleão Marcos de Moura Mendes (2005), Prática docente do ensino religioso em Teresina. $\mathrm{O}$ autor buscou em seu estudo a compreensão da prática docente dos professores de ER das escolas estaduais de ensino fundamental ( $5^{\mathrm{a}}$ à $8^{\mathrm{a}}$ séries) localizadas na capital piauiense. Deixando claro que a atual prática docente deve ser situada na história, Napoleão conclui apresentando caminhos para a superação dos dilemas que envolvem o professor e sua prática: a compreensão da (in)definição atual do Ensino Religioso, a superação das práticas tradicionais, a participação na organização de conteúdos e na elaboração do material didático, a luta pelo reconhecimento profissional e a tarefa de capacitação dos professores para o pluralismo e a cidadania.

A realidade mineira é o alvo de Maria Cristina Caetano (2007), que disserta sobre $O$ ensino religioso e a formação de seus professores: dificuldades e perspectivas (PUC Minas). Analisando a trajetória do ER e a formação de seus professores na região metropolitana de Belo Horizonte, a autora considerou o contexto atual e os documentos normativos, destacando o papel social dessa formação na vida dos profissionais e os saberes a ela inerentes.

Como problematização, apresentou as seguintes questões: como o Ensino Religioso é considerado nos documentos normativos e no contexto 
atual? Como se desenvolve a formação dos professores no contexto da educação brasileira? A formação de docentes para o ER tem conseguido prepará-los para o exercício da sua profissão, considerando a multiplicidade de dimensões, advindas do contexto social, antropológico e religioso dos alunos?

Alguns dos dados por ela sintetizados sobre a investigação realizada com docentes foram:

- as razões da escolha da profissão: "oportunidade" para lecionar a disciplina e completar carga horária, convite da direção e por sentir certa vocação;

- formação: falta de capacitação específica;

- participação em cursos de formação continuada, no início da carreira, visando ao credenciamento;

- ao longo da profissão, curso de graduação ou de pós-graduação na área específica;

- ligação entre teoria e prática;

- especificidade do trabalho com a disciplina, considerando que o magistério do Ensino Religioso requer uma dimensão mais humana e que a aprendizagem ocorre nas relações dialógicas;

- desvalorização / discriminação / precarização da disciplina, tanto no contexto da escola, quanto no campo das políticas públicas;

- dificuldades em trabalhar com a disciplina em sala de aula, encontrar fontes de pesquisa e material adequado;

- insegurança em ministrar temáticas relacionadas às religiões, demonstrando a carência de uma consistência teórico-conceitual;

- gratificação no magistério com a disciplina Ensino Religioso quando o trabalho é reconhecido e quando percebem o crescimento dos alunos;

- papel do docente de ER como orientador dos alunos;

- contribuição da disciplina para a formação moral, social e cognitiva dos alunos;

- procedimentos didáticos e temáticas usadas estão relacionados com as problemáticas dos alunos;

- pressupostos necessários à prática docente: “amor" pela disciplina;

- formação específica para o atendimento às demandas dos alunos, vivência cristã, trabalho coletivo; 
- comprometimento e postura do profissional, metodologia e linguagem adequadas, transposição didática do conhecimento, ética, capacidade de trabalhar com o pluralismo religioso e clareza quanto à sua experiência religiosa;

- dimensão da religiosidade, do sagrado, da espiritualidade, da ética e do fenômeno religioso, trabalhadas a partir das solicitações dos alunos. Nota-se insegurança dos professores em relação a essas abordagens;

- contribuição do Ensino Religioso para a formação discente, para a elaboração de um referencial de vida, baseado em princípios humanísticos, na construção da identidade dos alunos;

- avaliação da disciplina, processual e qualitativa, que privilegia a habilidade atitudinal; outros docentes continuam optando pela avaliação centrada nos conteúdos.

A autora propõe em suas considerações finais que o Ensino Religioso deve contribuir de modo mais efetivo para a formação dos alunos, desenvolvendo a imaginação e a capacidade criadora, incentivando a espontaneidade, a curiosidade, o questionamento de si mesmos, o respeito às diferenças, o sentimento de solidariedade e a compreensão da realidade que os circunda. Também aponta que é preciso desenvolver projetos educacionais multidisciplinares para o que ER assuma um papel integrador e humanista na formação discente.

\section{Subsídios para a formação docente}

O papel relevante da revista Diálogo (criada pela Editora Paulinas, em 1995) foi o alvo da pesquisa de mestrado de Claudia Regina Tavares Cardoso (2007). Em A contribuição da Revista Diálogopara a formação do professorleitor de ensino religioso (PUCPR), a autora procurou identificar as percepções sobre o ER de professores que se utilizaram dessa publicação, pela ótica da teoria do receptor-leitor.

Um dos pontos relevantes apresentados, como resultado da pesquisa, refere-se à utilização da revista pelos professores-leitores-receptores na continuidade da sua formação profissional. A autora constatou que o periódico auxilia no aprofundamento e atualização do fenômeno religioso, orienta e amplia o conhecimento dos leitores. Todos os entrevistados 
apontaram para a necessidade da formação continuada dos professores, assegurando uma atuação ligada aos valores e valorização do transcendente nas escolas.

Algumas das principais observações apresentadas após o levantamento teórico e análise dos dados obtidos nas pesquisas foram que a Revista Diálogo:

- propõe e cumpre o seu papel de veículo de comunicação com o professor-leitor;

- valoriza o professor-leitor-receptor no processo de comunicação;

- favorece a formação pessoal e profissional;

- auxilia na prática docente;

- proporciona subsídio à pesquisa, como fonte de formação básica;

- atualiza o leitor;

- subsidia a formação continuada do professor;

- propicia a busca de aprimoramento profissional.

Segundo a autora, o professor de ER, na função de mediador, por meio de uma construção pedagógica, religa o educando ao transcendente. $\mathrm{O}$ Ensino Religioso encontra espaço para levar o aluno à reflexão do sentido da sua vida, bem como ao compromisso responsável com a transformação da realidade segundo os valores religiosos. Portanto, a Revista Diálogo, do ponto de vista do professor-leitor-receptor, contribui para a formação docente do Ensino Religioso.

Claudino Gilz (2007), na sua dissertação sobre $A$ coleção "Redescobrindo o Universo Religioso" na formação do professor (PUCPR), buscou analisar em que sentido a citada coleção constitui um dos elementos formativos do professor que a utiliza em sala de aula.

Segundo Gilz, essa coleção apresenta-se como: um substrato para construção da experiência religiosa dos agentes escolares; portadora de uma intencionalidade educativa e formativa voltada à alteridade e à pesquisa; proposta de apoio ao trabalho docente; desenvolvimento metodológico propositivo; inovadora operacionalidade didática; sensível à faixa etária dos educandos; abertura de espaço para a participação; criatividade e coautoria dos docentes.

A partir das entrevistas que realizou com professores, o autor apresenta três contribuições da coleção à formação docente: opção de 
trabalhar de forma dialogal e respeitosa os temas da área de Ensino Religioso; estabelecimento de um vínculo entre ensino e pesquisa; trabalho docente atrelado ao "ser interior" e "atração" pelo sagrado.

Portanto, segundo Gilz, a coleção apresenta uma proposta de um ER interativo e reflexivo, que estimula a experiência do Transcendente, busca o equilíbrio entre ensino e pesquisa, contextualiza as temáticas e possibilita o exercício da docência com base nas evidências do fenômeno religioso.

\section{Fazer pedagógico}

Francisca Helena Cunha Daneliezen (2007) redigiu e defendeu dissertação na Universidade Regional de Blumenal, discutindo Interculturalidade e ensino religioso: olhares e leituras a partir de uma experiência pedagógica. Ela investiga como o currículo de Ensino Religioso aborda a questão da interculturalidade nas práticas pedagógicas, buscando referenciais teóricos para conceituar, discutir, refletir e enunciar indicadores para uma educação intercultural. A autora analisa um filme e fotos gravados em DVD que apresentam os resultados de uma prática pedagógica de ER a partir do tema "Cultura e Religiosidade Indígena”. Essa prática é parte integrante do projeto Respeitando as diferenças: uma nova perspectiva para o Ensino Religioso.

Um dos resultados identificados nessa prática pedagógica foi a constatação do aprofundamento dos conhecimentos da confessionalidade de cada educando, a sua identidade religiosa e a importância da convivência com as diferenças.

Nas considerações finais, a autora comenta que as práticas pedagógicas que integram a perspectiva intercultural, na prática cotidiana, promovem a relação entre diferentes culturas e contribuem para que educandos e educadores possam compreender e assumir outras posturas diante das diferentes realidades sociais, culturais e religiosas. Nota-se que a tarefa social do componente curricular de Ensino Religioso consta em desafiar educandos e educadores para novos olhares e leituras na perspectiva da construção de "outro mundo, melhor e possível" (DANELIEZEN, 2007, p. 78). Para isso, as práticas pedagógicas devem favorecer o acolhimento e respeito às diferenças.

Portanto, segundo a autora, essa pesquisa apresenta contribuições importantes para a criação de novas e efetivas propostas educacionais, em resposta às demandas e urgências do contexto intercultural da realidade 
brasileira. Um desafio que busca na alteridade e na diversidade cultural perspectivas e práticas para uma educação intercultural.

Em dissertação defendida na PUCRS, Marcos AndréScussel (2007) pesquisou Religiosidade bumana efazereducativo, apresentando o entendimento do ser humano como um ser religioso, e buscando construir uma compreensão da relação entre religiosidade humana e o fazer educativo. Estabeleceu nesse estudo um diálogo entre desenvolvimento espiritual, vida e educação, desenvolvimento da fé e desenvolvimento moral.

O autor comenta que o Ensino Religioso, como disciplina integrante do sistema educacional, é um processo de educação da dimensão religiosa do ser humano. Assim, o professor de ER precisa estar aberto ao outro, conviver com o diferente, conhecer e acolher as verdades de fé das tradições religiosas e precisa ter clareza da sua religiosidade.

Como resultado das pesquisas, ficou evidenciado que os educadores precisam tomar consciência de sua religiosidade, da relação desta com a sua vida e com o seu fazer educativo. Outras questões abordadas foram: a importância de proporcionar aos alunos o espaço do conhecimento, da partilha e do diálogo sobre o fenômeno religioso presente na vida e na cultura; e a necessidade de maior atenção quanto à dimensão do desenvolvimento humano na formação de educadores para o Ensino Religioso, nos cursos de formação de professores e nos cursos específicos.

\section{Considerações quase conclusivas}

Considerando a proposta do presente artigo em apresentar uma primeira aproximação ao levantamento ainda em andamento sobre teses e dissertações que enfocam a formação docente e o Ensino Religioso, realizadas apenas na área de Educação, cremos ser importante articular tal pensamento com a LDBEN e os PCNER.

A Lei n. 9.394, de 20 de dezembro de 1996 (LDBEN), em seu artigo 33 garante que o Ensino Religioso é parte integrante da formação básica do cidadão, assegurando o respeito à diversidade religiosa e que os sistemas de ensino regulamentarão os procedimentos para a definição dos conteúdos de ER e estabelecerão as normas para a habilitação e admissão do professor.

Segundo o Fonaper, a atual proposta de Ensino Religioso requer um profissional de educação com: 
formação adequada ao desempenho de sua ação educativa; abertura ao conhecimento e aprofundamento permanente de outras experiências religiosas além da sua; consciência e espírito sensível voltados à complexidade e pluralidade da questão religiosa; disposição ao diálogo, com capacidade de articulá-lo à luz das questões suscitadas no processo de aprendizagem dos estudantes; uma vivência de reverência à alteridade; capacidade de ser o interlocutor entre escola e comunidade, reconhecendo que a escola propicia a sociabilização do conhecimento religioso sistematizado, ao passo que a família e a comunidade religiosa são os espaços privilegiados para a vivência religiosa e para a opção de fé (FONAPER, 1997).

A partir das dissertações apresentadas sobre a temática formação docente no Ensino Religioso, pode-se dizer que todas apresentam a perspectiva do ER como espaço que possibilita o desenvolvimento humano e religioso do educando e do educador, num processo dialógico e de respeito à diversidade cultural e religiosa dos indivíduos, inseridos no contexto do mundo atual.

O papel do professor no Ensino Religioso é de fundamental importância para a concretização dos objetivos desta área de conhecimento. Portanto, constatam-se nessas dissertações e teses alguns desafios: 1) Segundo a LDBEN, exigência de um profissional portador de diploma de nível superior - necessidade de cursos de Licenciatura para atender a esta demanda. 2) Segundo o Fonaper, o ER requer um profissional com formação adequada para o desenvolvimento da ação educativa. Considerando tal premissa, verifica-se a importância de uma formação inicial e continuada que favoreça aos docentes uma nova visão sobre o Ensino Religioso, conhecimento sobre o fenômeno religioso e os PCNER, e reconhecimento do ER como área de conhecimento.

A partir do que se constatou nas pesquisas citadas, acredita-se que a proposta de estudo do fenômeno religioso deve estar inserida no cotidiano da escola, na pluralidade cultural e religiosa. Para tal, é fundamental uma formação continuada, que esteja agregada ao projeto da escola e que remeta às questões fundamentais da vida humana. A escola, como espaço de construção do conhecimento religioso, como espaço aberto à diversidade cultural e religiosa, como espaço de formação individual e coletiva para a cidadania, deve abraçar umprocesso de formaçãointegral para educandos e educadores. Reconhecendo tal pensamento como possibilidade de estabelecimento de estratégias que viabilizem a prática da filosofia educacional contida na legislação nacional 
e do projeto pedagógico escolar, pode-se vislumbrar um objetivo da escola para a formação docente no Ensino Religioso: contribuir para a formação integral do professor, ajudando-o no processo de aprendizagem dialógica, crítica e reflexiva sobre o seu fazer pedagógico e o seu ser pessoa.

Finalizando, destaca-se a relevância dos estudos realizados sobre a formação de professores de Ensino Religioso, priorizando a formação da pessoa do professor, como um mediador, um ser-em-relação, um ser social inserido em um contexto sócio-político-cultural e religioso, um ser em busca do transcendente e com capacidades a serem desenvolvidas. Os autores deste artigo consideram, portanto, algumas capacidades que devem ser cultivadas e trabalhadas pelos docentes em ER: capacidade de valorizar o ser humano e a natureza; de conviver com o diferente, atendendo à pluralidade cultural e religiosa, sem proselitismo; de estabelecer uma relação entre cultura e experiência religiosa; de um fazer pedagógico pautado na pesquisa e na reflexão sobre a teoria e a prática, que possibilitem a experiência do encontro consigo, com os outros, com o mundo e com o transcendente; de compreensão da linguagem simbólica na dimensão religiosa, como expressão dos sentimentos, vivências e desejos; de vivenciar experiências religiosas e comunitárias; de comprometer-se eticamente com a defesa da vida e a construção de uma cidadania ativa; de aprender a conbecer, fazer, conviver e ser; entre outras que podem ser complementadas pelos leitores e estudiosos desta temática.

Cremos que a formação docente é uma prática contínua e que este caminho deve ser empreendido, na perspectiva do desenvolvimento humano e religioso, inserido na complexidade do mundo atual.

\section{Referências}

ARAÚJO, D. C. R. Características do professor de ensino religioso dos anos finais do ensino fundamental e médio nas escolas católicas de Curitiba. 2007. 81 f. Dissertação (Mestrado em Educação) - Pontifícia Universidade Católica do Paraná, Curitiba, 2007.

BERTONI, J. C. Da legislação a prática docente: o ensino religioso nas escolas municipais de Santos. 2008. 280 f. Dissertação (Mestrado em Educação) Universidade Presbiteriana Mackenzie, São Paulo, 2008. 
BRASIL. Lei n. 9.394, de 20 de dezembro de 1996. Estabelece as diretrizes e bases da educação nacional. Diário Oficial [da] República Federativa do Brasil, Poder Legislativo, Brasília, DF, 23 dez. 1996. p. 27833. Disponível em: < http://www6.senado. gov.br/legislacao/ListaTextoIntegral.action?id=75723>. Acesso em: 23 jul. 2009.

CAETANO, M. C. O ensino religioso e a formação de seus professores: dificuldades e perspectivas. 2007. 386 f. Dissertação (Mestrado em Educação) Pontifícia Universidade Católica de Minas Gerais, Belo Horizonte, 2007.

CARDOSO, C. R. T. A contribuição da Revista Diálogo para a formação do professor-leitor de ensino religioso. 2007. 157 f. Dissertação (Mestrado em Educação) - Pontifícia Universidade Católica do Paraná, Curitiba, 2007.

CARON, L. Políticas e práticas curriculares: formação de professores de ensino religioso. 2007. 385 f. Tese (Doutorado em Educação: Currículo) - Pontifícia Universidade Católica de São Paulo, São Paulo, 2007.

CASTRO, I. P. Afetividade e mediação do professor do ensino religioso escolar. 2008. 87 f. Dissertação (Mestrado em Educação) - Universidade Federal do Pará, Pará, 2008.

CORRÊEA, B. R. P. G. A concepção dos professores sobre o sagrado: implicações para a formação docente. 2006. 128 f. Dissertação (Mestrado em Educação) - Pontifícia Universidade Católica do Paraná, Curitiba, 2006.

DANELIEZEN, F. H. C. Interculturalidade e ensino religioso: olhares e leituras a partir de uma experiência pedagógica. 2007. 85 f. Dissertação (Mestrado em Educação) - Universidade Regional de Blumenau, Santa Catarina, 2007.

DELORS, J. (Coord.). Os quatro pilares da educação. In: DELORS, J. Educação: um tesouro a descobrir. São Paulo: Cortez, 1996. p. 89-102.

FÓRUM NACIONAL PERMANENTE DO ENSINO RELIGIOSO FONAPER. Parâmetros Curriculares Nacionais: ensino religioso. 3. ed. São Paulo: Ave Maria, 1997.

GILZ, C. A coleção “Redescobrindo o Universo Religioso" na formação do professor. 2007. 152 f. Dissertação (Mestrado em Educação) - Pontifícia Universidade Católica do Paraná, Curitiba, 2007.

MACHADO, L. M. P. A cidadania na formação de professores para ensino religioso. 2006. 129 f. Dissertação (Mestrado em Educação) - Pontifícia Universidade Católica do Paraná, Curitiba, 2006. 
MENDES, N. M. M. Prática docente do ensino religioso em Teresina - PI. 2005. 210 f. Dissertação (Mestrado em Educação) - Universidade Federal do Piauí, Piauí, 2005. Disponível em: <http://www.gper.com.br/?sec=mestrado >. Acesso em: 21 set. 2005.

MESNSLIN, D. J. Perfil do professor de ensino religioso nos anos iniciais do ensino fundamental da rede educacional adventista no Sul do Brasil. 2009. 139 f. Dissertação (Mestrado em Educação) - Pontifícia Universidade Católica do Paraná, Curitiba, 2009.

RODRIGUES, E. M. F. Em riscos e rabiscos: concepções de ensino religioso dos docentes do ensino fundamental do Estado do Paraná - possibilidade para uma formação docente. 2008. 190 f. Dissertação (Mestrado em Educação) - Pontifícia Universidade Católica do Paraná, Curitiba, 2008.

SANTOS, S. F. Perfil do professor de Ensino Religioso da educação infantil e dos anos iniciais do ensino fundamental na Escola Confessional Católica. 2007. 74 f. Dissertação (Mestrado em Educação) - Pontifícia Universidade Católica do Paraná, Curitiba, 2007.

SCHLÖGL, E. Não basta abrir as janelas: o simbólico na formação do professor. 2005. 225 f. Dissertação (Mestrado em Educação) - Pontifícia Universidade Católica do Paraná, Paraná, 2005.

SCUSSEL, M. A. Religiosidade humana e fazer educativo. 2007. 177 f. Dissertação (Mestrado em Educação) - Pontifícia Universidade Católica do Rio Grande do Sul, Rio Grande do Sul, 2007.

SEEHABER, L. C. Cultura, lente pela qual se vê o mundo: o universo cultural do professor de ensino religioso. 2006. 161 f. Dissertação (Mestrado em Educação) - Pontifícia Universidade Católica do Paraná, Curitiba, 2006.

VIEIRA, E. A. Os ritos: como um dos eixos organizadores do currículo do ensino religioso e a formação do professor. 2006. 118 f. Dissertação (Mestrado em Educação) - Pontifícia Universidade Católica do Paraná, Curitiba, 2006.

Recebido: $14 / 03 / 2010$ Received: 03/14/2010

Aprovado: $25 / 05 / 2010$ Approved: 05/25/2010 